RESIDENT

\& FELLOW

SECTION

Section Editor

Mitchell S.V. Elkind, MD, MS

Max R. Lowden, MD Gary A. Thomas, MD

Address correspondence and reprint requests to Dr. Max R. Lowden, Department of Neurology-EC037, Penn State College of Medicine Milton S Hershey Medical Center, P.O. Box 859, 30 Hope Drive, Hershey, PA 17033

Mlowden@hmc.psu.edu

\section{Teaching NeuroImages: Superficial siderosis}

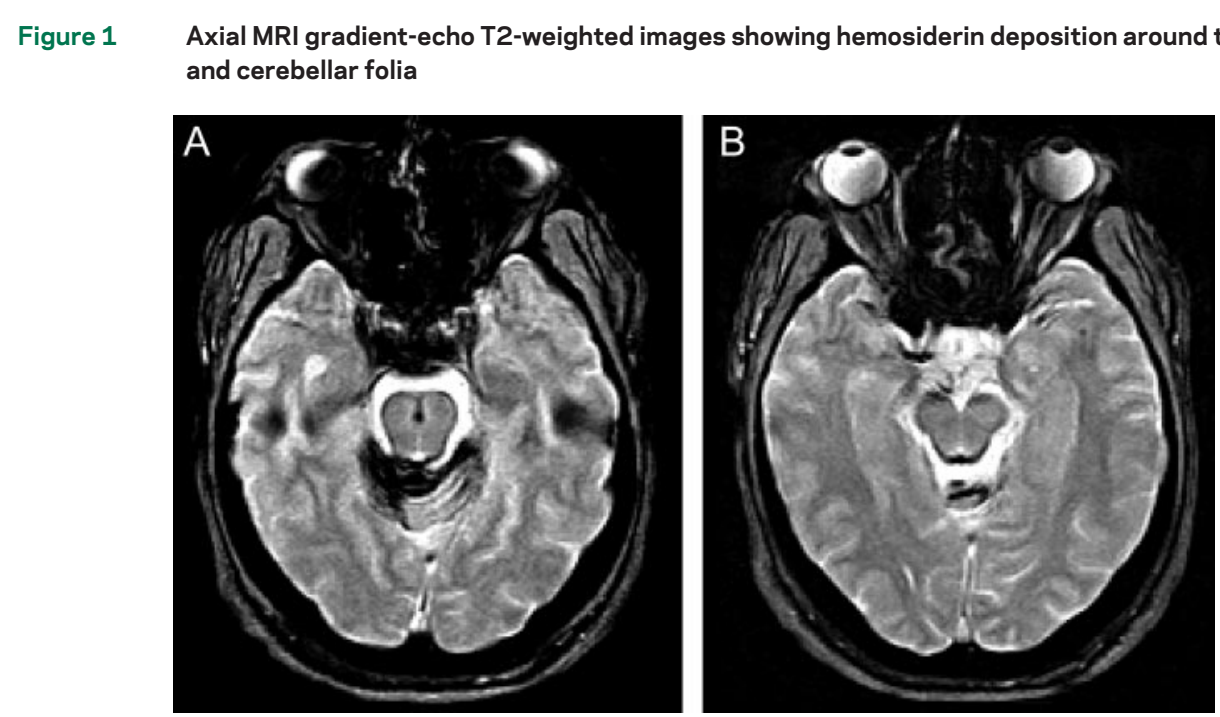

A 47-year-old man had progressive lower extremity weakness and incoordination for 2 years. Examination showed bilateral proximal lower

\section{Figure 2 Axial MRI gradient-echo T2-weighted image showing a rim of hypodensity around the upper cervical cord (A) and medulla (B)}
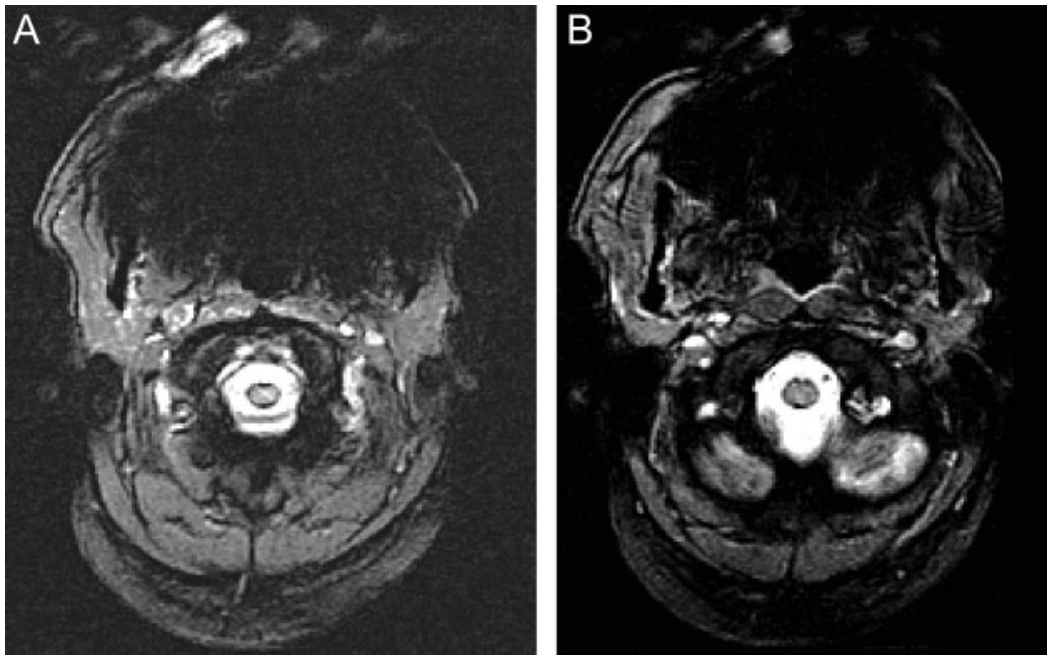

The circumferential T2 hypointensity is due to hemosiderin deposition. extremity weakness, cerebellar ataxia, and brisk reflexes throughout. Cranial nerve examination showed hearing impairment. MRI showed hemosiderin deposition around the brainstem, cerebellum, and upper cervical cord (figures 1 and 2). CSF analyses showed protein of $108 \mathrm{mg} / \mathrm{dL}$ and red blood cells of $58 \mathrm{~mm}^{3}$.

Superficial siderosis most commonly presents with gait ataxia and hearing loss. It is caused by repeated slow hemorrhage into the subarachnoid space with CNS hemosiderin deposition in the subpial layers. ${ }^{1}$ Imaging of the entire neuroaxis is indicated to localize a potential bleeding source, and may include cerebral and spinal angiography. ${ }^{2}$

\section{REFERENCES}

1. Kumar N, Cohen-Gadol AA, Wright RA, Miller GM, Piepgras DG, Ahiskog JE. Superficial siderosis. Neurology 2006;66:1144-1152.

2. Kumar N. Superficial siderosis: associations and therapeutic implications. Arch Neurol 2007;64:491-496.

From the Department of Neurology, The Pennsylvania State University Milton S. Hershey Medical Center College of Medicine, Hershey, PA. Disclosure: The authors report no disclosures. 


\title{
Neurology
}

\author{
Teaching NeuroImages: Superficial siderosis \\ Max R. Lowden and Gary A. Thomas \\ Neurology 2009;72; 39 \\ DOI 10.1212/01.wnl.0000343053.13886.7e
}

This information is current as of February 23, 2009

\author{
Updated Information \& \\ Services \\ Supplementary Material \\ References \\ Permissions \& Licensing \\ Reprints
}

including high resolution figures, can be found at: http://n.neurology.org/content/72/8/e39.full

Supplementary material can be found at: http://n.neurology.org/content/suppl/2009/07/08/72.8.e39.DC1

This article cites 2 articles, 1 of which you can access for free at: http://n.neurology.org/content/72/8/e39.full\#ref-list-1

Information about reproducing this article in parts (figures,tables) or in its entirety can be found online at:

http://www.neurology.org/about/about_the_journal\#permissions

Information about ordering reprints can be found online:

http://n.neurology.org/subscribers/advertise

Neurology ${ }^{\circledR}$ is the official journal of the American Academy of Neurology. Published continuously since 1951, it is now a weekly with 48 issues per year. Copyright . All rights reserved. Print ISSN: 0028-3878. Online ISSN: 1526-632X.

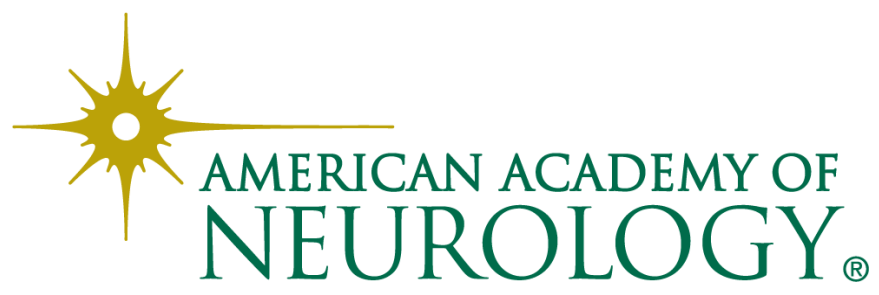

